\title{
Let's Argue: \\ Using Debate to Teach Critical Thinking and Communication Skills to Future Leaders
}

\author{
Michael Chikeleze \\ Associate Professor \\ LSU Shreveport \\ Iris Johnson \\ Professor \\ LSU Shreveport \\ Trey Gibson \\ Bradley S. Kemp Professor of Debate \\ LSU Shreveport
}

\begin{abstract}
Some employers contend that the college graduates they hire should have stronger communication and critical thinking skills upon arrival from their various college/university programs in which they majored. As higher education continues its efforts to meet the demands for employers, the authors contend that the benefits of participation in debate exercises can be incorporated into various courses as a teaching tool to increase facility with these soft skills. A practical application of debate in a specific organizational leadership course is presented, along with highlights of the student participants' reflections upon the experience, and the initial signs of positive impact on these skills. Suggestions of future application of debate into curricula are also shared.
\end{abstract}

\section{Issue Statement}

On April 18, 2017, the United Airlines CEO exhibited the importance of critical thinking and communication skills as he offered an initial response to the forceful removal of a passenger on an overbooked flight (Victor \& Stevens, 2017). For the public relations debacle that ensued, the CEO later issued both written and video apologies in an attempt to thwart the public's initial negative impression of the incident. This scenario brings home the type of critical thinking skills, now needed by employees at any level in an organization, so as Harter (2009) proclaimed, "No matter what the world might throw at them, these graduates could cope when the situation turned volatile, uncertain, complex, and ambiguous" (p. 111). Some may argue that this need is even more critical when a prompt, thoughtful response may be expected during the age of Instagram, Twitter, and 24-hour news coverage. At issue is the notion that employers need employees and organizational leaders to possess the needed critical thinking and communications skills, yet there is often scarce return on these expectations (The Official GMAT Blog, 2014).

According to some employers, some graduates from colleges and universities often leave without desirable soft skills, or may otherwise be underprepared for successful transition to the 
workplace (Elliot, 2015; Gallup, Inc., 2014; Harris, 2015; Jones, Baldi, Phillips, \& Waikar, 2016; Roska \& Arem, 2012; Society for Human Resource Management [SHRM], 2008; Stewart, Wall, \& Marciniec, 2016; Tugend, 2013; Vassal, 2014). In a study commissioned by the Chronicle of Higher Education and the American Public Media, slightly more than $40 \%$ of the 704 employers responding to the survey indicated that knowledge of content area (42.5\%) or technical skills associated with the job (45.5\%) were very important in new hires. However, more than $50 \%$ of those employers identified skills they considered more important: soft skills of written and oral communication (78.8\%) and making decisions and solving problems (59.3\%) (Maguire Associates, Inc., 2013, p. 12).

College graduates also acknowledge problems of inadequate preparation and lack of confidence, with regards to the soft skills of communication and critical thinking as supported by their higher education institutions (Craig, 2016; Head, 2016; Pascarella, Blaich, Martin, \& Hanson, 2011). For example, a survey of 1,651 college graduates who recently entered the workforce revealed that only $30 \%$ of the respondents felt that they obtained sufficient critical thinking skills in college (Head, 2016). Perhaps some juxtapositioning of these research claims of inadequacy is in order. Two basic positions demand some attention: (a) a call to carefully consider the research methodology used to report those claims of inadequacy (Lane \& Oswald, 2016; Lederman, 2013); and (b) a reminder that undergraduate studies merely represent a foundation for learning, and that learning must continue — with practice (Posner, 2009). Considering the latter premise, we would like to suggest that some soft-skill development in the form of academic debate can support deliberate practice for improving soft skills. Additionally, debate can help improve confidence as students learn to provide substantive impromptu responses to challenging questions.

'If students are to 'get their money's worth' from the classroom experience, it is important that as much valuable classroom time be spent on higher level analysis, integration, and experiential education rather than the simple mastery of basic course principles" (Navarro, 2008, p. 118). It is incumbent upon professors to "ground their curriculum in real-world experience so millennials are prepared for life-long learning beyond campus gates" (Larson \& Metzger, 2013, para. 11). This life-long learning requires critical thinking and communication skills to maneuver in the life-in general, and in the workplace, specifically. Clearly, finding innovative and creative ways to teach communication and critical thinking skills that can extend beyond the classroom is an important issue faced by institutions of higher education.

This article suggests we return to the college classrooms to explore a promising, instructional tool-scholarly debate - to boost the soft skills of college students who will eventually become employees. We contend that experience debating in various academic courses in colleges and universities can increase students' communication and critical thinking skills. We adopt Bartanen and Frank's (1994) definition of debate as "a competitive speaking activity between two or more people arguing about a proposition of policy or judgment under mutually agreed-upon rules in front of a listener(s) who has responsibility to decide who did a better job of debating, using whatever criteria the listener deems important" (p. 3). Such an exercise, we contend, incorporated as part of a course, can help students improve their communication and critical thinking skills. 
Many colleges and universities have debate teams that operate as co-curricular or extracurricular activities on campus; however, we contend that adopting or adapting these practices and skills for use in the classroom will support long-term communication and critical thinking skills for college students. Those involved in debate societies or student clubs on campus can create training programs to assist professors - from any discipline - in incorporating competitive debate into their curriculum. Teaching key argumentation skills, assisting with curriculum planning to use debate as an instructional tool in the classroom, and facilitating students in experiencing debate themselves, will support growth in the desired skills, along with confidence in using them. In the end, faculty will have a greater understanding of how debate may be applied and how they can facilitate it in their individual disciplines. As a result, students will improve communication skills, exhibit stronger critical thinking skills, and ultimately be better prepared for the workplace upon graduation.

\section{Literature Review}

A review of the literature brings attention to three major aspects in this article: critical thinking skills, scholarly debate, and the intersection of the two. In this section, we will briefly share a definition of critical thinking — from an individual and group perspective - and a rationale for its importance in the workplace. We will follow with clarity on the role debate can play in supporting the acquisition, practice, and fine-tuning of critical thinking skills and other soft skills desired by college graduates who enter the workforce.

"Critical thinking is a process of purposeful, self-regulatory judgment that gives reasoned consideration to evidence, contexts, conceptualizations, methods, and criteria" (Cone et al., 2016, p. 1). This definition of critical thinking seems apropos for study in education, management, and medicine - to merely name a few areas - while supporting the claim that this skill is "crossdisciplinary...can be achieved in college... [and is] required for success in the workplace, higher academics, and life in general" (CAE, 2013, p. 2). Critical thinking requires deep knowledge, and the ability to apply that knowledge to new, novel, or authentic situations. Tiruneh et al. (2016) considered the work of notable researchers in the late 1980s and late 1990s (i.e., Ennis, 1989, Halpern, 1998) and surmised that "critical thinking involves the ability to clearly and precisely raise vital questions, gather relevant information and reach well-reasoned conclusions, make accurate decisions, assess the credibility of sources, identify cause-effect relationships, and effectively communicate with others in figuring out solutions" (p. 482).

Harter (2009) indicates that critical thinking skills that may be taught in college classrooms focus on more than just work "in isolation - perceiving, thinking, and drawing inferences - but rather how to participate in groups of people attempting to reason together" (p. 112). It is this description that offers a seemingly perfect segue to introduce the notion of academic debate as a tool for fine-tuning two major soft skills needed in leadership education: critical thinking skills and communication skills. A comprehensive review of the published literature confirmed support for the use of debate to improve "students' critical thinking...engagement in learning...listening skills... arguing skills...content knowledge...selfesteem...global thinking... and empathy for perspective other than their own" (Tessier, 2009, p. 144). Keeping this group of soft skills in mind, and recognizing that debates may be delivered in a variety of ways, we will share some basic notions about debate formats. 
Using a preliminary categorization of academic debate by Cirlin (2007) there are at least six basic formats of debate as acknowledged by the International Public Debate Association (IPDA): "the British Union Debate..., the National Debate Tournament (NDT)..., the LincolnDouglas (LD)..., the Worlds [sometimes referred to as British or Parliamentary] Format..., the 3/4-Person Format..., and the Public Debate" (pp. 5-12). The majority of these formats typically use two teams of two members to debate each other. Exceptions are the Lincoln-Douglas and Public debates, which typically use two teams of one member each; the 3/4-Person format, which offers a variation on the British Union Debate with three or four people debating; and the Worlds Format which uses four teams of two debaters each. Other formats of debate, somewhat similar to these six basic formats identify such formats as team debate, middle school or high school debate, classroom debate, mock trials, cross-examinations, or policy debate (https://idebate.org/debate-formats?utm-source-twitterfeed\&utm-medium=twitter; Llano, 2012; Tessier, 2009).

Debate teams typically deliver their view-points, positions, or arguments in the contexts of affirmative/negative; government/opposition; or constructive/rebuttal stances (Cirlin, 2007). Three examples will be shared briefly: one from a specific debate format; one from a college classroom setting; and one from a medical school scenario with resident physicians and interns. In a British Union Debate format two teams may debate " 8 minutes each for [four] constructive speeches and one 5-minute rebuttal speech by each side" (Cirlin, 2007, p. 5). In an undergraduate course on environmental issues, four classroom debate formats (i.e., standard, panel, student questions, and pre-set questions) were explored using combinations of two teams, with or without non-debating class members participating as a jury or panel with writers (Tessier, 2009, p. 144). In the student questions format, debaters prepared opening statements to share their responses to questions that had been given to them in advance by classmates; responded to rebuttals by the team representing the opposition; and then offering closing statements (Tessier, 2009, p. 145). In our final example, with emergency medicine (EM) residents the "EM Debates" required two teams each comprised of a senior-level resident and attendants to respond to a case presented by a moderator (Mamtani, Scott, DeRoos, \& Conlon, 2015). Soft skills, content knowledge, and simulated real-world scenarios were brought to bear in these "evidence-based discussions."

Many of these debate types refer to an Affirmative/Negative argument; however, the terms Government/Opposition may also be used, respectively (Cirlin, 2007). A single topic, multiple topics, or a group of topics may be offered, with the privilege to strike away undesirable topics, until a target topic is identified for debate. A specified period of research may follow; however, "the IPDA format expressly forbids the reading of evidence" (Cirlin, 2007, p. 14). The debate categories identified by Cirlin (2007) focus more on debate in competition; however, instructional use of debate allows for another categorization. Healey (2012) broadened the scope of debate in instructional settings by referring to the following eight forms: "(a) two students debating; (b) panel debate; (c) instructor debate; (d) role play debate; (e) graded debate; (f) structured debate; (g) unstructured debate; and (h) online debate" (p. 252). The six categories identified by Cirlin (2007) may all fit within the structured debate category as shared by Healey (2012). 
In making the case for the intersection of critical thinking skills and the benefits of debate, specific subsets of critical thinking skill have been identified by Moon's 2008 study (as cited in Healey, 2012): "critical thinking as appraisal, evaluation, reflection, understanding, analysis, review, appreciation, management, awareness, care; critical thinking as incident analysis; and critical thinking as problem-solving and decision-making" (p. 242). Considering those critical thinking skills, the information that follows is provided to support the conclusion that argumentation skills and participation on debate teams in college and secondary school levels carry many academic benefits, including typically higher GPAs for debaters than those who do not debate (Kennedy, 2009; Mezuk, Bondarenko, Smith \& Tucker, 2011; PartlowLefevre, 2012; Rogers, 2002). Specifically, of the 20 benefits of debate identified by Rogers (2002), "academic success...psychological adjustment... and higher rates of critical thinking activities" (p. 5) than non-debaters were noted.

At the secondary school level, we share two examples: the first on a relatively small scale with 40 students (Othman, Sahamid, Zulkefli, Hashim, \& Mohamad, 2015), and the latter on a larger scale with 9,000 students (Mezuk et al., 2011). An examination of 16-year olds who participated in debate over a 3-week period indicated "a significant difference in their critical thinking skills before and after the debate activity" (Othman et al., 2015, p. 656). Results of a study comparing debaters and non-debaters in Chicago Public Schools indicated that debaters "were more likely to graduate from high school, performed better on the ACT, and showed greater gains in cumulative GPA relative to similar comparison students" (Mezuk et al., 2011, p. 630).

Benefits of the use of debate as a specific instructional tool in university classroom settings such as accounting, economics, education, marketing, medicine, pharmacy, and social work also show possible links to critical-thinking skills (Healey, 2012). In Kennedy's (2009) research involving a series of five debates with education students self-reports in post-tests indicated that their knowledge of the issues increased due to their participation in related debates, and possibly contributed to "between $31 \%$ and $58 \%$ of the participants chang[ing] their opinion after each of the five debates" (p. 232). The use of debate in accounting classes was linked to "a significant increase in awareness and confidence with respect to information gathering and higher order synthesis of that information... [along with] an opportunity to hone their critical thinking skills" (Camp \& Schnader, 2010, p. 668). The use of debate as a curriculum tool—verbally or in writing - is not limited to traditional face-to-face learning. Lin and Crawford (2007) applied debate to an online pharmacy course, and discovered that "the requirement of students to compose written arguments for the text-based online debates was considered by students as one of the benefits they gained from the assignment" (p. 6).

In addition to students' benefits for participation in debate, instructors have also shared positive reflections on the experience and recommended the use of debate to their teaching colleagues (Camp \& Schnader, 2010). Similarly, Kennedy (2009) found that $85.7 \%$ of prospective teachers who participated in the classroom debates indicated that they "would consider having their students participate in a debate" (p. 229). Without further delay, we are pleased to note that the descriptions of critical thinking skills posited thus far seem directly related to the experiences and the types of knowledge and thinking that should occur to participate in scholarly debate of the variety described here. Accepting this brief review of the 
literature, in support of the use of debate in the classroom to meet various academic goals, including increased proficiency in communication and critical thinking skills, leads to a consideration of the specific application of debate in this study.

\section{Discussion of the Application}

A university professor incorporated a public debate activity into the curriculum of a leadership studies' policy analysis course during the 2016 summer academic session. The catalog description for the course - although not specifically designed for debate, might certainly suggest the potential for debate: "An analysis of public policy at the federal, state, and local levels, with particular attention to current issues in the political environment with broad, intergovernmental implications" (course syllabus). The relevant course outcomes indicated that students will be able to identify and apply (a) critical elements of policy approaches, and (b) theories of knowledge relevant to policy analysis. In consultation with the university's director of debate, the professor concluded that debate could be a valuable tool for meeting the course outcomes as students would be called upon to demonstrate their ability to communicate and apply critical thinking skills to political and economic issues of public policy. In addition to the assigned required readings, papers, and case studies, the syllabus indicated that "each student [is required] to form teams, and participate in one debate on a political or economic policy issue ... using the [Bardach \& Patashnik, 2016)] steps of policy analysis to reach your desired result to solving a public problem" (course syllabus). The three authors of this paper supported distinct roles in promoting this story, and possibly suggest future alliances for instructors who may seek to apply the use of debate as an instructional tool in their classes. The first author, the course professor, proposed the implementation of debate in the policy analysis class after witnessing the debate competition successes of the university's debate director, who happened to be a graduate student enrolled in the course. The second author, the university's debate director, provided professional development about debate as an instructional tool for the other authors approximately two weeks prior to the targeted class, in addition to a debate orientation session for students enrolled in the targeted course. The third author observed the university's debate team during a local competition during preparation and competition, and also served as a debate judge for one competition.

The four-point debate orientation for the students enrolled in the targeted course focused on ways to be effective debate team members as they were given debate rules and practices: (a) instructions on the 38-minute time format (i.e., four alternating 7-minute affirmative-negative constructive sessions each, followed by two 5-minute rebuttals); (b) explanation of the parliamentary style of debate (constructive and rebuttal); (c) instructions regarding how to pose questions during a debate; and (d) instructions on points of order. Information on stock issues (Bates, 2002) regarding significant harms, inherency, topicality, and solvency as experienced in policy debates was also provided. In support of the training, four undergraduate students from the university's debate team demonstrated a mock debate for the class.

The course professor identified relevant debate topics that matched the course outcomes and, in alignment with expectations from previous related research, was able to successfully "[exhibit] the same argumentation processes found in UK [United Kingdom] teachers who had participated in an extensive professional development program and were effective in improving 
students' argumentation skills" (Dawson \& Venville, 2008, p. 144). Putting debate into action as an instructional tool for the graduate class, began with the professor forming six debate teams of three students on each team $(n=18)$. Each team was given - at random-either an affirmative or a negative position to posit, based on one of the three debate topics. Each debate topic was based on one of three federal government policy concerns.

- Team 1 (affirmative) \& Team 2 (negative): “The U.S. Federal Government should pass legislation to mandate free tuition to any public 4-year higher education institution."

- Team 3 (affirmative) \& Team 4 (negative): “The Federal Government should complete the XL Pipeline."

- Team 5 (affirmative) \& Team 6 (negative): "The Federal Government should 'ban the box' for those convicted of felony crimes."

All topics were designed to increase communication and critical thinking skills of the participants, while supporting mastery of the required course outcomes with regards to policy analysis and development. The professor asked teams, when they were not debating, to observe other teams, and provide written feedback to them. All teams debated the topics, over two class sessions (four hours each), using the parliamentary style of debate (American Parliamentary Debate Association, 2016), with the schedule and time format listed below.

- First affirmative constructive (7 minutes)

- First negative constructive (7 minutes)

- Second affirmative constructive (7 minutes)

- Second negative constructive (7 minutes)

- Negative rebuttal (5 minutes)

- Affirmative rebuttal (5 minutes)

\section{Discussion of the Outcomes}

The primary expected outcome for this experience was two-fold: (a) for the course instructor to have a greater knowledge and understanding of debate and how it may be used beneficially to support learning in the specific discipline; and (b) for the student participants to have a greater knowledge and understanding of the course content through a rich, learning experience designed to also improve their use of such soft skills as critical thinking and effective communication through the use of debate. The debate director also conducted pre- and postsemi-structured interviews with the professor, examining his knowledge of argumentation and debate. The outcome was that the instructor had an increased knowledge of debate as well as knowledge of a variety of ways that debate might be used to support learning, communication, and critical thinking in the policy course.

As the second expected outcome focused on debaters' perceptions that their skills in communication and critical thinking had improved, a survey was distributed approximately six months after the debate experience to support the assessment of this outcome. One way to assess such outcomes follows Kennedy's (2009) approach in using an open-ended post-test to gain feedback from students who participated in the debates. In this case, the professor asked the 
students about their experiences with a 14-item anonymous survey posted in the classroom learning management system (i.e., Moodle). The questionnaire included 13 items for which Likert-type responses (e.g., $1=$ strongly disagree to $5=$ strongly agree) were provided, and one open-ended item to share additional feedback about the debate experience. As we considered the possible advantages of positively-keyed items over a mixture of positive- and negative-keyed items to address bias there were 13 positively stated Likert-type items (Sauro, 2011). Students were given five days to respond to the survey. Of the 18 students who participated in the debate activity, 15 students (approximately $83 \%$ ) responded to the Likert-type items, and 4 (approximately 22\%) provided qualitative comments to the open-ended item. Cronbach's alpha for the 13 items was relatively strong $(\alpha=.741)$.

\section{Table 1.}

Results of Students Responses to Items 1 and 2 Regarding Increased Communication and Critical Thinking Skills as a Result of Participating in a Debate Activity $(n=15)$

\begin{tabular}{lccccc}
\hline Item Number & Strongly Disagree & Disagree & Neither & Agree & Strongly Agree \\
\hline Item 1 & $6.7 \%$ & $13.3 \%$ & $26.7 \%$ & $40.0 \%$ & $13.3 \%$ \\
Item 2 & $0.0 \%$ & $0.0 \%$ & $6.7 \%$ & $80.0 \%$ & $13.3 \%$ \\
\hline
\end{tabular}

Item 1: My communication skills increased as a result of debate activity.

Item 2: My critical thinking skills increased as a result of debate activity.

The results (as shown in Table 1 above) show that $53.3 \%$ and $93.3 \%$ of the students strongly agreed or agreed that their communication skills and critical thinking skills increased, respectively. The results supported the conclusion that the use of debate in a content course can help to support students in the development of communication and critical thinking skills that are important for success in the workplace.

Other questionnaire items that provided insight regarding the debater's perception that specific critical thinking skills had improved during the debate experience are reflected in the responses to Items 7-10 and 12 in Table 2. 
Table 2.

Results of Students Responses to Items 7-13 Regarding Specific Critical Thinking Skills Accommodated through the Debate Experience $(n=15)$

\begin{tabular}{lccccc}
\hline Item Number & Strongly Disagree & Disagree & Neither & Agree & Strongly Agree \\
\hline Item 7 & $0.0 \%$ & $0.0 \%$ & $20.0 \%$ & $60.0 \%$ & $20.0 \%$ \\
Item 8 & $6.7 \%$ & $6.7 \%$ & $13.3 \%$ & $60.0 \%$ & $13.3 \%$ \\
Item 9 & $0.0 \%$ & $13.3 \%$ & $26.7 \%$ & $60.0 \%$ & $0.0 \%$ \\
Item 10 & $0.0 \%$ & $13.3 \%$ & $0.0 \%$ & $66.7 \%$ & $20.0 \%$ \\
Item 12 & $0.0 \%$ & $6.7 \%$ & $0.0 \%$ & $60.0 \%$ & $33.3 \%$ \\
\hline
\end{tabular}

Item 7: The debate activity helped me to think fast.

Item 8: My reasoning skills have improved as a result of participating in policy debate.

Item 9: Participating in the debate increased my ability to solve problems.

Item 10: I was able to take in large chunks of information as a result of participating in debate.

Item 12: The debate activity helped me to better defend my position.

Additionally, the impact of the debate was investigated as it relates to course content learning, and Pearson's RED model of critical thinking (recognize assumptions [R], evaluate arguments [E], and draw conclusions [D]), to further determine their self-reported perception of increased critical thinking skills (Pearson, 2009). As indicated below (Table 3), the self-reported survey results indicate an increase in knowledge of the content of the course as well as components of critical thinking.

Question 3: My knowledge of policy analysis increased after participating in the debate.

Question 4: I was able to see the positive and negative points of the argument as a result of participating in the debate.

Question 5: Participating in the debate helped me to increase my skills in formulating and asking probing questions.

Question 6: The debate helped me be more critical of the assumptions the opponents made.

\section{Table 3.}

Results of Students Responses to Questions 3-6 Regarding Learning about Policy Analysis, Debate, and Increased Skill in Asking Probing Questions or Critical Thinking $(n=15)$

\begin{tabular}{lccrcc}
\hline Item Number & Strongly Disagree & Disagree & Neither & Agree & Strongly Agree \\
\hline Item 3 & $0.0 \%$ & $6.7 \%$ & $0.0 \%$ & $66.7 \%$ & $26.7 \%$ \\
Item 4 & $6.7 \%$ & $33.3 \%$ & $6.7 \%$ & $46.7 \%$ & $6.7 \%$ \\
Item 5 & $0.0 \%$ & $13.3 \%$ & $6.7 \%$ & $66.7 \%$ & $13.3 \%$ \\
Item 6 & $0.0 \%$ & $6.7 \%$ & $0.0 \%$ & $53.3 \%$ & $40.0 \%$ \\
\hline
\end{tabular}


Lastly, the survey results demonstrated qualitative support for positive experiences by the students. One student noted "loved it; definitely keep the exercise for future cohorts." Another said it was a "Great application activity. Allowed me to reflect on how I would possibly act in stressful situation." One other student responded that "although I was not fond of the idea at first, it wasn't as bad as I thought it would be. I truly enjoyed the debate experience."

\section{Reflections of the Practitioner}

The purpose of this exercise was to determine if incorporating debate in the curriculum would increase students' communication and critical thinking skills. The idea was to provide debate instruction and curriculum assistance for faculty to use debate as a tool in their individual classrooms. This instructional approach has probably been used in a variety of subjects, such as psychology, personality studies, environmental issues, medical schools, and public policy. With the research that has been published regarding employers' disappointment with critical thinking and communication skills of graduates, and the popularity of debate in addressing content and such skills (Tessier, 2009), this study supports the belief in the potential for the use of debate as an instructional tool to support students' attainment or improvement in soft skills and application of content knowledge. We sought to use debate as an innovative teaching tool to teach policy analysis, as arguing a position is an important part of the course outcomes. We observed the initial trepidation of many students in realizing they had to argue their positions in front of the class, and then be able to respond when challenged by their opponents. We were pleasantly surprised by the growth in students' confidence, ability to think fast, challenge assumptions, and critically think about complex policy issues. It was truly remarkable. In an era where persuasion is more important than ever, we believe it was a worthwhile exercise and encourage faculty to investigate its use in their own classrooms.

\section{Recommendations}

The information learned helps justify the debate exercise by highlighting its strengths, and may help improve it by identifying areas of improvement when debate is used in the future. The strength of this exercise is that faculty may benefit by enhancing their classroom experience and students may benefit from perceived increased communication and critical thinking skills as a result of participating in debate. If so, employers represent a secondary level benefactor as the initiator of complaints about the current status of college graduates. Presumably, if students leave universities with stronger communication and critical thinking skills then employers benefit. Therefore, we encourage the use of debate by professors in their technical courses.

However, while we were able to gather data about the students' perceptions of their debate experience and other anecdotal evidence, future research can improve our conclusions by collecting and analyzing data on the actual (versus perceived) impact of debate on these skills. For example, pre-tests and post-tests (such as surveys, papers or oral presentations) could be given to students participating in debates, to determine how successful debate as used in the classroom improved their communication and critical thinking skills. This could begin by, for example, evaluating initial skills and then again, after being trained and participating in debate. This could help establish the increased proficiency levels of communication and critical thinking, that resulted through participation in debate, beyond the perceived results that we found. Also, 
faculty and students who used debate in the classroom could provide additional detailed and open-ended feedback. After review of open-ended feedback, follow-up interviews with faculty and student participants may reveal further information. Many of these ideas are scheduled for use in upcoming courses at the authors' institution.

Nonetheless, given that the preliminary data shows that students perceive the benefits of debate in improving their communication and critical thinking skills, and that literature supports positive results, the authors contend that further research should be done in this area, in other courses and in other colleges and universities.

\section{References}

American Parliamentary Debate Association. (2016). A guide to parliamentary debate: The rules of parliamentary debate. Retrieved from http://www.apdaweb.org/old/guide/rules.html

Bardach, E., \& Patashnik, E.M. (2016). A practical guide for policy analysis: The eightfold path to more effective problem solving. $\left(5^{\text {th }} \mathrm{ed}\right.$.) Los Angeles, CA: Sage Publications.

Bartanen, M. D. \& Frank, D. A. (1994). Nonpolicy Debate. Upper Saddle River, NJ: Prentice Hall.

Bates, B. R. (2002). Inherency, strategy and academic debate. Rostrum, 76(5), 15-18. Retrieved from https://debate.uvm.edu/NFL/rostrumlib/cxBates10102.pdf

Camp, J., \& Schnader A. (2010). Using debate to enhance critical thinking in the accounting classroom: The Sarbanes-Oxley Act and U.S. tax policy. Issues in Accounting Education. 25(4): 655-675. doi: 10.2308/iace.2010.25.4.655.

Cirlin, A. (2007). Academic debate v. advocacy in the real world: A comparative analysis. The International Public Debate Association (IPDA) Journal, 1(1), 3-18. Retrieved from http://www.ipdadebate.info/uploads/4/9/8/1/4981933/v1n1_p_3_18.pdf

Cone, C., Godwin, D., Salazar, K., Bond, R., Thompson, M., \& Myers, O. (2016). Incorporation of an explicit critical-thinking curriculum to improve pharmacy students' critical-thinking skills. American Journal of Pharmaceutical Education, 80(3), 1-5.

Council for Aid to Education (CAE) (2013). Does college matter? Measuring critical-thinking outcomes using the CLA. Retrieved from http://cae.org/images/uploads/pdf/Does_College_Matter.pdf.

Craig, W. (2016, March). Most grads say college taught them few critical thinking skills. Entrepreneur. Retrieved from: https://www.entrepreneur.com/article/270077

Dawson, V., \& Venville, G. (2008). Teaching strategies for developing students' argumentation skills about socioscientific issues in high school genetics. Research Science Education, 40, 133-148. doi: 10.1007/s11165-008-9104-y. 
Elliot, M. (2015, May). 5 skills grads need to get a job. USA Today. Retrieved from http://www.usatoday.com/story/money/personalfinance/2015/05/03/cheat-sheet-skillscollege-grads-job/26574631/

Gallup, Inc. (2014). The 2013 Lumina study of the American public's opinion on higher education and U.S. business leaders poll on higher education: What America needs to know about higher education redesign. Retrieved from https://www.luminafoundation.org/files/resources/2013-gallup-lumina-foundationreport.pdf

Hackman, M. \& Johnson, C. (2013). Leadership: A communication perspective. (6th ed). Long Grove, IL: Waveland Press, Inc.

Harris, B. (2015, September). The status of critical thinking in the workplace. Pearson Education. Retrieved from http://www.pearsoned.com/education-blog/the-status-ofcritical-thinking-in-the-workplace/

Harter, N. (2009). Critical thinking in groups. Journal of Leadership Education, 8(1), 111-117. Retrieved from http://www.journalofleadershiped.org/attachments/article/202/JOLE_8_1_Harter.pdf

Head, A. J. (2016). Staying smart: How today's graduates continue to learn once they complete college. Project Information Literacy Research Report. University of Washington. Retrieved from https://ssrn.com/abstract=2712329 or http://dx.doi.org/10.2139/ssrn.2712329

Healey, R. L. (2012). The power of debate: Reflections on the potential of debates for engaging students in critical thinking about controversial topics. Journal of Geography in Higher Education, 36(2), 239-257.

Jones, M., Baldi, C., Phillips, C., \& Waikar, A. (2016). The hard truth about soft skills: What recruiters look for in business graduates. College Student Journal, 50(3), 422-428.

Kennedy, R. (2009). The power of in-class debates. Active Learning in Higher Education, 10(3), 225-236. doi: 10.1177/146978740343186.

Lane, D., \& Oswald, F. (2016). Do 45\% of college students lack critical thinking skills? Revisiting a central conclusion of academically adrift. Educational Measurement: Issues and Practice, 35(3), 23-25. doi:10.1111/emip.12120

Larson, G., \& Metzger, M. (2013, December). Why everyone is wrong about working with millennials. Fast Company. Retrieved from https://www.fastcompany.com/3022520/why-everyone-is-wrong-about-working-with$\underline{\text { millennials }}$ 
Lederman, D. (2013, May 20). Less academically adrift? Assessment and accountability. Inside Higher Education. American Association of University Professors (AAUP). Retrieved from https://www.insidehighered.com/news/2013/05/20/studies-challenge-findingsacademically-adrift

Lin, S., \& Crawford, S. (2007). Innovations in teaching: An online debate series for first-year pharmacy students. American Journal of Pharmaceutical Education, 71(1), 1-8. Retrieved from http://www.ajpe.org/doi/pdf/10.5688/aj710112

Llano, S. M. (2012). One if by land, two if by sea, three if by format: British debate is coming. Contemporary Argumentation \& Debate, 33, 171-186.

Maguire Associates, Inc. (2013). The role of higher education in career development: Employer perceptions. The Chronicle of Higher Education and Marketplace. Retrieved from http://www.chronicle.com/items/biz/pdf/Employers\%20Survey.pdf

Mamtani, M., Scott, K. R., DeRoos, F. J., \& Conlon, L. W. (2015). Assessing EM patient safety and quality improvement milestones using a novel debate format. Western Journal of Emergency Medicine: Integrating Emergency Care with Population Health, 16(6), 943946. doi:10.5811/westjem.2015.9.27269

Mezuk, B., Bondarenko, I., Smith, S., \& Tucker, E. (2011). Impact of participating in a policy debate on academic achievement. Evidence for the Chicago Urban Debate League. Educational Research and Reviews, 6(9), 622-632.

Navarro, P. (2008). The MBA core curricula of top-ranked U.S. business schools: A study in failure? Academy of Management Learning and Education, 7(1), 108-123. Retrieved from:

https://webfiles.uci.edu/navarrop/public/article\%20hyperlinks/The\%20MBA\%20Core\%2 0Curriculum.pdf

Othman, M., Sahamid, H., Zulkefli, M., Hashim, R., \& Mohamad, F. (2015). The effects of debate competition on critical thinking among Malaysian second language learners. Middle-East Journal of Scientific Research, 23(4), 656-664. doi: 10.5829/idosi.mejsr.2015.23.04.22001.

Partlow-Lefevre, S. (2012). Arguing for debate: Introducing key components for assessment of intercollegiate debate programs. Contemporary Argumentation and Debate, 33, 31-74. Retrieved from http://www.cedadebate.org/files/2012CADFinal.pdf\#page=41

Pascarella, E. T., Blaich, C., Martin, G. L., \& Hanson, J. M. (2011). How robust are the findings of academically adrift? Change, 43(3), 20-24. doi:10.1080/00091383.2011.568898

Pearson (2009, October 22). Learn Pearson's RED critical thinking model. Retrieved from http://critical-thinkers.com/2009/10/learn-pearsons-red-model/ 
Posner, B. Z. (2009). From inside out: Beyond teaching about leadership. Journal of Leadership Education, 8(1), 1-10. Retrieved from http://www.journalofleadershiped.org/attachments/article/208/JOLE_8_1_Posner.pdf

Rogers, J. E. (2002). Longitudinal outcome assessment for forensics: Does participation in intercollegiate, competitive forensics contribute to measureable differences in positive student outcomes? Contemporary Argumentation and Debate, 23, 1-27.

Roska, J., \& Arem, R. (2012). Life after college: The challenging transitions of the academically adrift cohort. Change, 44(4), 8-14. doi:10.1080/00091383.2012.691857

Sauro, J. (2011, April). Are both positive and negative items necessary in questionnaires? MeasuringU.com. Retrieved from https://measuringu.com/positive-negative/

Society for Human Resource Management (SHRM), and Wall Street Journal.com/Careers (2008). Critical skills needs and resources for the changing workforce. Retrieved from http://www.octech.edu/Content/Uploads/octech.edu/files/Critical\%20Skills\%20Needs\%2 0and\%20Resources\%20for\%20the\%20Changing\%20Workforce\%20Survey\%20Report.p $\underline{\mathrm{df}}$

Stewart, C., Wall, A., \& Marciniec, S. (2016). Mixed signals: Do college graduates have the soft skills that employers want? Competition Forum, 14(2), 276-281.

The Official GMAT Blog. (2014, August 7). Employers want communication skills in new hires. The GMAT Blog Hub. Retrieved from http://www.mba.com/us/the-gmat-blog-hub/theofficial-gmat-blog/2014/aug/employers-want-communication-skills-in-new-hires.aspx

Tessier, J. T. (2009). Classroom debate format. College Teaching, 57(3), 144-152.

Tiruneh, D., Weldeslassie, A., Kassa, A., Tefera, Z., Cock, M., \& Elen, J. (2016). Systematic design of a learning environment for domain-specific and domain-general critical thinking skills. Educational Technology Research \& Development, 64(3), 481-505. doi:10.1007/s11423-015-9417-2

Tugend, A. (2013, June 28). What it takes to make new college graduates employable. The New York Times, 162, SectB. Retrieved from http://www.nytimes.com/2013/06/29/yourmoney/a-quest-to-make-college-graduates-employable.html? $\mathrm{r}=0$

Vassel, K. (2014, January 30). The skills employers wish college grads had. Fox Business. Retrieved from http://www.foxbusiness.com/features/2014/01/30/skills-employers-wishcollege-grads-had.html

Victor, D. \& Stevens, M. (2017). United Airlines passenger is dragged from an overbooked flight. The New York Times. Retrieved from https://www.nytimes.com/2017/04/10/business/united-flight-passenger-dragged.html?_r=0 


\section{Author Biographies}

Michael Chikeleze, Ph.D. is an Associate Professor and Chair of the Department of Leadership Studies at LSU Shreveport. Email: michael.chikeleze@1sus.edu

Iris D. Johnson, Ph.D. is a Professor and Program Director of the doctoral program in leadership studies at LSU Shreveport. Email: iris.johnson@1sus.edu

Trey Gibson is the Bradley S. Kemp Professor of Debate at LSU Shreveport. Email: Trey.gibson@1sus.edu 